\title{
Effects of Exogenous Oxytocin on Embryonic Survival in Cows
}

\author{
A. YILDIZ, Z. ERISIR \\ Department of Dairy Animal Breeding, College of Sivrice, University of Firat, Turkey
}

Received October 22, 2004

Accepted November 10, 2005

\begin{abstract}
Yildiz A., Z. Erisir: Effects of Exogenous Oxytocin on Embryonic Survival in Cows. Acta Vet Brno 2006, 75: 73-78.

The aim of this study was to evaluate the effect of oxytocin on embryonic survival in dairy cows. Pregnancy was verified using the early pregnancy factor (EPF) activity on Day 4 after artificial insemination (AI). Pregnant cows were randomly allotted to two groups: treated $(n=8)$ and control $(\mathrm{n}=8)$. Oxytocin (100 IU, $5 \mathrm{ml}$, DIF Turkey) was administered twice daily by intravenous injections to treated cows and sterile saline $(5 \mathrm{ml})$ to control cows immediately before milking on days 4 to 7 after AI. Blood samples were taken via jugular vein every day from day 4 to 8 and every other day until Day 20 following insemination to evaluate the effect of oxytocin on embryonic survival. The embryonic loss was diagnosed in 3 of the 8 cows treated with oxytocin, and embryonic survival rate was $62.5 \%$ in this group versus $87.5 \%$ in controls. Short cycles occurred in $37.5 \%$ of oxytocin-treated cows. At the same time their serum progesterone concentrations rose more slowly than in controls. It was concluded that cows administered oxytocin on days 4 to 7 after insemination are at a higher risk of pregnancy loss.
\end{abstract}

Conception rate, embryonic mortality, short cycle, progesterone

Reproductive performance in the cattle industry is arguably lower than desired. Early embryonic mortality is one of the major problems in animal breeding. Conception rates among cattle have been reported to be as high as $90 \%$, yet calving rates are in the range of 50 to $60 \%$ (Sreenan and Diskin 1983) or lower, and much of this decline can be attributed to embryonic mortality. Progesterone synthesis by the corpus luteum (CL) is necessary for maintenance of early pregnancy in the cow (Stewart 1990). Premature regression of the $\mathrm{CL}$ and the subsequent reduction in progesterone secretion results in loss of pregnancy (Thatcher et al. 1994). Exogenous oxytocin is often used by dairies to increase milk letdown (Farin and Estill 1993; Lemaster et al. 1999). Oxytocin leads to luteal regression by driving the release of prostaglandin $\mathrm{F}_{2 \alpha}\left(\mathrm{PGF}_{2 \alpha}\right)$ from the endometrium (Balaguer 1999). It may induce release of $\mathrm{PGF}_{2 \alpha}$ in pregnant cows and ewes (Burgess et al. 1990) albeit at a level much lower than that observed in cycling animals (La France and G off 1985). Several researchers have demonstrated an increased release of $\mathrm{PGF}_{2 \alpha}$ after injections of oxytocin, which resulted in shortened luteal phases in cows (New comb et al. 1977; Milvae and Hansel 1980; Fuchs et al. 1996). Regression of the corpus luteum leads to a decline in circulating progesterone and deprivation of the fetus of nutrient support. This may result in abortion. Some studies reported that oxytocin influenced progesterone production from corpus luteum (Lemaster et al. 1999; Tan et al. 1982). However, other authors (Mares and Casida 1963; Richardson and Mass on 1985) have not observed an effect of oxytocin on progesterone production. To our knowledge, the effect of oxytocin on embryonic loss has not been studied yet. Therefore, the objective of this work was to evaluate the effect of oxytocin on embryonic survival in dairy cows.

\section{Materials and Methods}

Holstein cows aged 3 - 5 years were used in this experiment. All animals were clinically healthy. The estrus of cows was synchronized with two intramuscular injections of $526 \mu \mathrm{g}$ Cloprostenol (Estrumate, DIF Turkey) eleven

Address for correspondence:

Yrd. Doç. Dr. Atilla YILDIZ

Firat Üniversitesi, Sivrice Meslek Yüksekokulu

Süt Hayvanciligi Programi, Elazig, Turkey

\author{
Phone: +90424 23700 00/4131 \\ Fax: +904242360846 \\ E-mail: ayildiz1@firat.edu.tr \\ http://www.vfu.cz/acta-vet/actavet.htm
}


days apart (Day 0). All cows were artificially inseminated (AI) with semen from a single Holstein bull of known high fertility at $12 \mathrm{~h}$ past detection of estrus. The experiment was conducted in accordance with the guidelines on animal welfare under the protocol approved by Ethical Committee of Veterinary Faculty of Firat University, Turkey.

The Early Conception Factor (ECF) is a glycoprotein and occurs in blood $48 \mathrm{~h}$ after conception. Early pregnancy factor $(E P F)$ is a protein called specific gamma interferon and a secreted substance with growth regulatory and immunomodulatory properties that is required for successful establishment of pregnancy. EPF has important characteristics that render it a superior applicant for an early chemical signal between the embryo and mother (Morton 1998). The detection of EPF in pregnant animals has thus important implications for the study of embryonic-maternal signaling in mammals (Cruz et al. 2001). EPF is needed for survival of the embryo during the pre and peri-implantation stages of pregnancy (Igarashi 1987; Athanas as et al. 1989; Athanas as-Platsis et al. 1991, 2000). It is detectable in maternal serum within $24 \mathrm{~h}$ of fertilization in all species studied so far (Morton 1998). Its values are higher in pregnant than in non-pregnant cows 2 days after AI (Ko 1998). Although it is not a certain indicator of pregnancy, EPF activity can be used as a method for early pregnancy diagnosis in cattle (Sakonju et al. 1993). In our experiment, serum EPF activity for confirmation of pregnancy on Day 4 following insemination was used. Non-pregnant cows were removed from the trial. Pregnant cows were randomly allotted to two groups as treated $(\mathrm{n}=8)$ and control $(\mathrm{n}=8)$. Oxytocin $(100 \mathrm{IU}, 5 \mathrm{ml}$, DIF Turkey) was given twice daily by IV injections to treated group and sterile saline $(5 \mathrm{ml})$ to control group immediately before milking on days $4-7$ after AI. Serum EPF activity was repeatedly used to confirm whether pregnancy was sustained throughout the study along with progesterone to evaluate the effect of oxytocin. Rectal palpation was also performed in cows not seen in estrus on day 45 after AI to confirm pregnancy. Blood samples were taken via jugular vein every day from day 4 to 8 and every other day until Day 20 post insemination. Blood samples were allowed to clot; the serum was removed, incubated at $56^{\circ} \mathrm{C}$ for 30 minutes, and then stored at $-20^{\circ} \mathrm{C}$ until assayed.

Serum was assayed for progesterone by radioimmunoassay (A commercial assay kit, Coat-a-Count; Diagnostic Products Corporation, Los Angeles, CA) as described in detail by Yildiz (1999). The inter- and intra-assay coefficients of variation were 10.8 and $9.5 \%$, respectively. The sensitivity of the assay was $15 \mathrm{pg} / \mathrm{tube}$.

Serum EPF activity was assayed using the rosette inhibition test (RIT). The test is well documented (Morton et al. 1974, 1976; Rolfe et al. 1984; Cavanagh and Morton 1996). This test is based on the capacity of lymphocytes, in the presence of guinea-pig serum as a source of complement, to bind heterologous erythrocytes to their cell surface (rosette formation) (B ach and Antoine 1968). The rosette inhibition test does not give a $100 \%$ reliable result but it is so far the only applicable method to detect the presence of EPF at concentrations at which it normally appears in vivo (Morton 1998). The assay was carried out as described by Sakonju et al. (1993) and Yildiz (1999). In summary, the lymphocyte suspension $(0.1 \mathrm{ml})$, previously incubated with diluted test serum, was incubated at $37{ }^{\circ} \mathrm{C}$ for $90 \mathrm{~min}$ with absorbed diluted guinea-pig complement $(0.05 \mathrm{ml})$ and anti-lymphocyte serum, serially double-diluted over a range of 1 in $128 \times 10^{3}$. Rosettes were formed by adding a suspension $(0.1 \mathrm{ml})$ of sheep red blood cells, centrifuging the mixture at $120 \mathrm{~g}$ for $5 \mathrm{~min}$, and re-suspending it gently by rotation and pipetting. The suspension was then spread on a Rosenthal counting chamber and the numbers of rosettes in all divisions were counted. The rosette inhibition titer (RIT) was defined as the highest dilution of anti-lymphocyte serum causing a reduction of at least $25 \%$ in the rosette number compared to the proportion of rosettes in the two tubes without antiserum. This titer was multiplied by $1 / 500$ and recorded as the logarithm to base 2 .

Data analysis

Females were declared non-pregnant when serum RIT was $<5$ (Yildiz and Deveci 2000). Verification of short cycle was determined by progesterone concentration $(\mathrm{P} 4<1.0 \mathrm{ng} / \mathrm{ml})$. At each stage after AI, data were analyzed by T-test (SPSS 1999).

\section{Results}

The effect of oxytocin on embryonic survival is shown in Fig. 1. Embryonic loss occurred in 3 of 8 cows on days 7 (in 2 of 8 cows) and 12 (in 1 of 8 cows) following the oxytocin injection. However, pregnancy was not maintained in 1 of the 8 pregnant cows in control group as diagnosed on Day 10 . Thus the embryonic survival rate was $62.5 \%$ in oxytocin group versus $87.5 \%$ in controls on Day 15 after insemination.

The incidence of short luteal phases was observed during this experiment (Fig. 2). Progesterone concentration in 3 of the 8 cows on days 10 (in 2 of cows 8) and 14 (in 1 of cows 8 ) was below $1.0 \mathrm{ng} \cdot \mathrm{ml}^{-1}$. Pregnant cows in the oxytocin group had lower progesterone (P4) levels compared to pregnant cows in the control group on days $8(P<0.05), 12(P<$ $0.05), 14(P<0.01), 16(P<0.05), 18(P<0.05)$ and $20(P<0.01)$. Short cycles were shown in oxytocin group $(3 / 8)$ in comparison with the control $(0 / 8)$. Short cycles occurred in $37.5 \%$ of those cows that received oxytocin. However, only 1 of the 8 cows in control group returned to estrus during the trial period. 


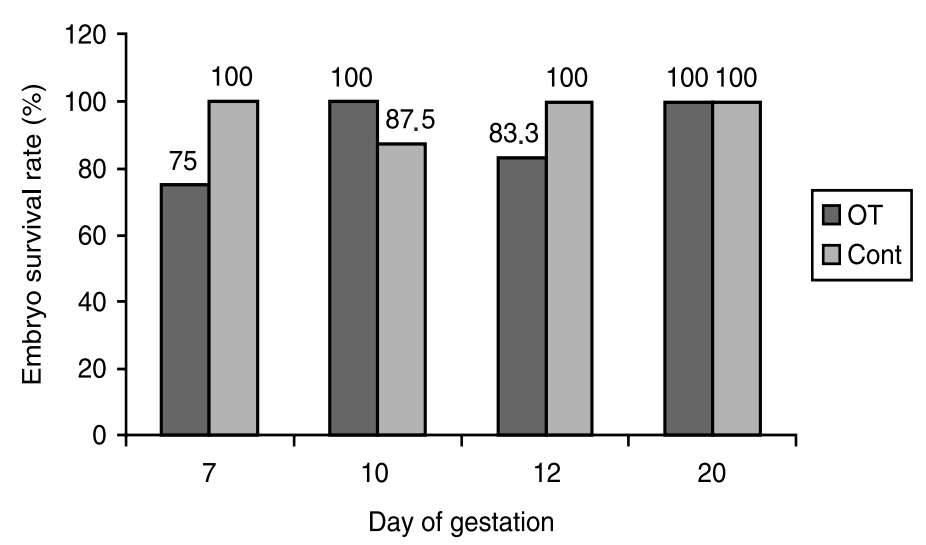

Fig. 1. Embryo survival rate in control cows and in oxytocin infused cows

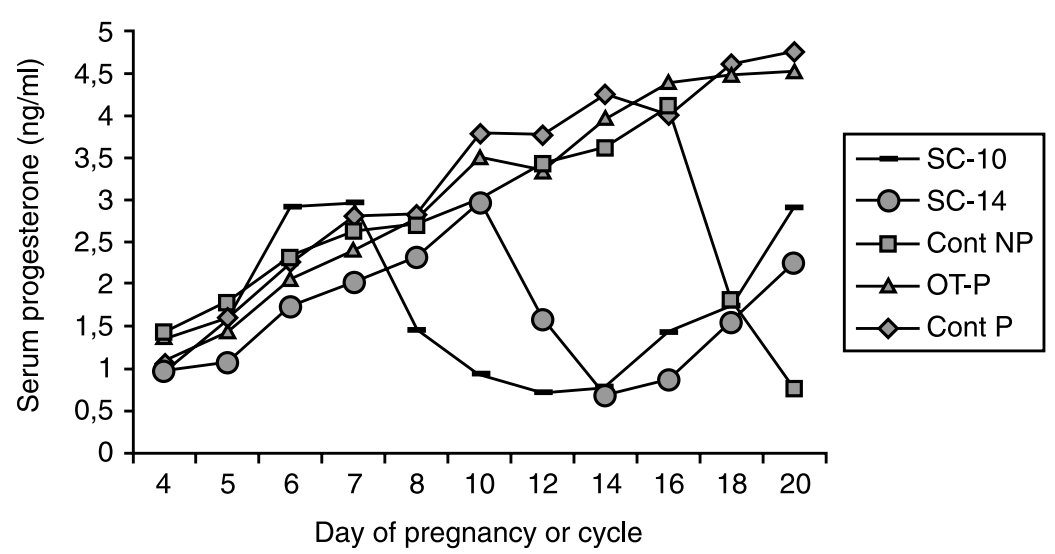

Fig. 2. Progesterone concentration of pregnant (Cont P) and non-pregnant (Cont NP) in control cows, and short cycle of days 10 (SC-10) and 14 (SC-14), and pregnant (OT-P) in oxytocin infused cows. Data are means, with standard errors omitted for clarity

\section{Discussion}

The results of our study have shown negative effects of oxytocin on the embryonic survival. Overall, all pregnant cows responded to the oxytocin injection with a reduction in serum P4. Percentage of pregnancy was significantly lower in the experimental group given oxytocin in comparison with the control group. These results are in agreement with previous studies reporting responsiveness to an oxytocin bolus of the early pregnant cows (Lemaster et al. 1999; B a laguer 1999). Generally the effects of oxytocin on pregnancy are insufficiently described. Oxytocin infusion can block the establishment of pregnancy (Wathes et al. 1991). Interaction with oxytocin receptors in the oviduct (Ayad et al. 1990) can influence embryo transport. The indirect effects of oxytocin by stimulation of uterine $\mathrm{PGF}_{2 \alpha}$ on establishment of pregnancy in cows seem reasonable (Lemaster et al 1999). Oxytocin stimulates the secretion of $\mathrm{PGF}_{2 \alpha}$ from the endometrium (Burns et al. 1997; Balaguer 1999). PGF $_{2 \alpha}$ plays a detrimental role in oxytocin-induced embryonic 
loss, aside from luteal regression (Balaguer 1999; Fuchs et al. 1996; Lemaster et al. 1999).

Monitoring of plasma P4 following oxytocin injection on days 4 to 7 of gestation suggested that luteal function in three cows was impaired after the injection of oxytocin but remained functional in five of the eight cows. The regression of the CL occurred in 3 of 8 cows given oxytocin on days 4 to 7 after insemination. These results are similar to those of Balaguer (1999) and Lemaster et al. (1999) and Tallam et al. (2000). Oxytocin can stimulate the release of sufficient $\mathrm{PGF}_{2 \alpha}$ to initiate luteolysis, even though uterine oxytocin receptor concentration is very low in early pregnancy (Sheldrick and Flint 1985). Fuch s et al. (1996) indicated that oxytocin caused luteal regression by stimulating endometrial secretion of $\mathrm{PGF}_{2 \alpha} \cdot \mathrm{PGF}_{2 \alpha}$ disrupts luteal secretion of progesterone, resulting in loss of pregnancy.

Serum concentrations of progesterone declined after oxytocin injection. In the oxytocininfused animals, the serum progesterone concentrations rose more slowly than in the controls. These results agree with the earlier studies of Le master et al. (1999) and Milvae and Hansel (1980). Schams (1987) reported that sensitivity to oxytocin might differ with the stage of pregnancy. Wath es et al. (1991) suggested that oxytocin infusions could inhibit luteal development. Pitzel et al. (1990) reported that oxytocin inhibited progesterone secretion in vitro. Tan et al. (1982) observed that high concentrations of oxytocin inhibited gonadotrophin-stimulated secretion of progesterone from bovine corpus luteum of early pregnancy in vitro. Sernia et al. (1991) observed that progesterone secretion was inhibited by a direct action of oxytocin. Low progesterone concentrations in the early luteal phase are detrimental to embryo survival, probably via an effect on the uterine environment (Wilmut et al. 1985; Ashworth et al. 1989).

In conclusion, using oxytocin twice daily immediately before milking on days 4 to 7 in cows induced luteal regression in 3 of 8 cows and decreased the pregnancy rate. For this reason it seems likely that cows given oxytocin during this period, are at a higher risk of pregnancy loss.

\section{Vliv exogenního oxytocinu na životnost embryí krav}

Účelem studie bylo vyhodnotit vliv oxytocinu na životnost bovinních embryí. Březost byla ověřována pomocí aktivity faktoru časné březosti (early pregnancy factor, EPF) čtvrtý den po umělé inseminaci. Březí krávy byly náhodně rozděleny do skupiny pokusné $(\mathrm{n}=8)$ a kontrolní $(n=8)$. Čtvrtý až sedmý den po umělé inseminaci byl bezprostředně před dojením pokusné skupině podáván dvakrát denně intravenózně (5 ml, DIF, Turkey) oxytocin (100 IU) a kontrolní skupině fyziologický roztok $(5 \mathrm{ml})$. K zjištění účinků oxytocinu na životnost embryí byly z v. jugularis 4. až 8. den a dále každý druhý den až do 20. dne po inseminaci odebírány krevní vzorky. Ztráta embrya byla zjištěna u 3 z 8 krav, jimž byl podáván oxytocin. U těchto krav tedy embrya přežila v $62,5 \%$ př́padů, naproti tomu u kontrolní skupiny přežilo 87,5\% embryí. U 37,5\% krav, kterým byl podán oxytocin, se vyskytly krátké cykly. Koncentrace progesteronu v séru se zvyšovaly ve srovnání s kontrolní skupinou pomaleji u krav, jimž byl aplikován oxytocin. Z práce vyplývá, že u krav, kterým je podáván v období mezi 4.-7. dnem oxytocin, je zvýšené riziko ztráty embrya.

\section{References}

ASHWORTH CJ, SALES DJ, WILMUT, I 1989: Evidence of an association between the survival of embryos and the periovulatory plasma progesterone concentration in the ewe. J Reprod Fertil 87: 23-32

ATHANASAS S, QUINN KA, WONG T-Y, ROLFE BE, CAVANAGH AC, MORTON H 1989: Passive immunisation of pregnant mice against early pregnancy factor (EPF) causes loss of embryonic viability. J Reprod Fertil 87: 495-502 
ATHANASAS-PLATSIS S, CORCORAN CM, KAYE PL, CAVANAGH AC, MORTON H 2000: Early pregnancy factor is required at two important stages of development in the mouse. Amer J Reprod Immunol 43: 223-233

ATHANASAS-PLATSIS S, MORTON H, DUNGLISON GF, KAYE PL 1991: Antibodies to early pregnancy factor retard embryonic development in vitro. J Reprod Fertil 92: 443-451

AYAD VJ, MCGOFF SA, WATHES DC 1990: Oxytocin receptors in the oviduct during the oestrous cycle of the ewe. J Endocrinol 124: 353-359

BACH JF, ANTOINE B 1968: In vitro detection of immunosuppressive activity of anti-lymphocyte sera. Nature 217: 658-659

BALAGUER S 1999: Early Pregnancy Responsiveness to an Oxytocin Challenge. J Undergraduate Res. University Scholars Program. University of Florida.

BURGESS KM, RALPH MM, JENKIN G, THORBURN GD 1990: Effect of oxytocin and estradiol on uterine prostaglandin release in nonpregnant and early-pregnant ewes. Biol Reprod 42: 822-832

BURNS PD, GRAF GA, HAYES SH, SILVIA WJ 1997: Cellular mechanisms by which oxytocin stimulates uterine PGF2 alpha synthesis in bovine endometrium: roles of phospholipases C and A2. Domest Anim Endocrinol 14: 181-191

CAVANAGH AC, MORTON H 1996: EPF: embryo detector and molecular chaperone. Today's Life Sci 8: 24-27

CRUZ YP, SELWOOD L, MORTON H, CAVANAGH AC 2001: Significance of serum early pregnancy factor concentrations during pregnancy and embryonic development in Sminthopsis macroura (Spencer) (Marsupialia: Dasyuridae). Reproduction 121: 933-939

FARIN PW, ESTILL CT 1993: Infertility due to abnormalities of the ovaries in cattle. Vet Clin N Amer-Food Anim Pr 9: 291-308

FUCHS AR, ROLLYSON MK, MEYER M, FIELDS MJ, MINIX JM, RANDEL RD 1996: Oxytocin induces prostaglandin F2 $\alpha$ release in pregnant cows: Influence of gestational age and oxytocin receptor concentrations. Biol Reprod 54: 647-653

IGARASHI S 1987: Significance of early pregnancy factor (EPF) on reproductive immunology. Acta Obstet Gynecol Jpn 39: 189-194

KO YG, SEONG HH, BACK KS, LEE MS, PARK SJ, IM GS, SIN WJ 1998: Early pregnancy diagnosis by the early pregnancy factor and the progesterone concentration in serum of Korean Native (Hanwoo) cattle. RDA J Livestock Sci 40: 28-35

LA FRANCE M, GOFF AK 1985: Effect of pregnancy on oxytocin-induced release of prostaglandin F2a in heifers. Biol Reprod 33: 1113-1119

LEMASTER JW, SEALS RC, HOPKINS FM, SHRICK FN 1999: Effects of administration of oxytocin on embryonic survival in progestogen supplemented cattle. Prostaglandins 57: 259-268

MARES SE, CASIDA LE 1963: Effect of exogenous oxytocin on the progestogen content of the bovine corpus luteum. Endocrinology 72: 79-82

MILVAE RA, HANSEL W 1980: Concurrent uterine venous and ovarian arterial prostaglandin F concentrations in heifers treated with oxytocin. J Reprod Fertil 60: 7-15

MORTON H 1998: Early pregnancy factor: an extracellular chaperonin 10 homologue. Immun Cell Biol 76: $483-$ 496

MORTON H, HEGH V, CLUNIE GJA 1974: Immunosuppression detected in pregnant mice by rosette inhibition test. Nature 249: 459-460

MORTON H, HEGH V, CLUNIE GJA 1976: Studies of the rosette inhibition test in pregnant mice: evidence of immunosuppression? Proc Roy Soc London Ser B 193: 413-419

NEWCOMB R, BOOTH WD, ROWSON LEA 1977: The effect of oxytocin treatment on the levels of prostaglandin $\mathrm{F}$ in the blood of heifers. J Reprod Fertil 49: 17-24

PITZEL L, JARRY H, WUTTKE W 1990: Effects of oxytocin on in vitro steroid release of midstage small and large porcine luteal cells. Endocrinology 126: 2343-2349

RICHARDSON MC, MASSON GM 1985: Lack of direct inhibitory action of oxytocin on progesterone production by dispersed cells from human corpus luteum. J Endocrinol 104: 149-151

ROLFE BE, CAVANAGH AC, FORDE C, BASTI F, CHEN C, MORTON H 1984: Modified rosette inhibition test with mouse lymphocytes for detection of early pregnancy factor in human pregnancy serum. $\mathrm{J}$ Immunol Method 70: 1-11

SAKONJU S., ENOMOTO S, KAMINURA S, AMANA K 1993: Monitoring bovine embryo viability with early pregnancy factor. J Vet Med Sci 55: 271-274

SCHAMS D 1987: Luteal peptides and intracellular communication. J Reprod Fertil 34: 87-99

SERNIA C, GEMMELL RT, THOMAS WG 1991: Effect of intra-ovarian infusion of oxytocin on plasma progesterone concentrations in pregnant ewes. J Reprod Fertil 92: 453-460

SHELDRICK EL, FLINT APF 1985: Endocrine control of uterine oxytocin receptors in the ewe. J Endocrinol 106: 249-258

SPSS 1999: SPSS Statistical Package for Social Sciences for Windows, SPSS Inc Chicago II.

SREENAN M, DISKIN MG 1983: Early embryonic mortality in the cow: Its relationship with progesterone concentration. Vet Rec 112: 517-521 
STEWART HJ 1990: Trophoblastic factors and the maternal recognition of pregnancy in sheep and cattle. J Dev Physiol 14: 115-23

TALLAM SK, WALTON JS, JOHNSON WH 2000: Effects of oxytocin on cloprostenol-induced luteolysis, follicular growth, ovulation and corpus luteum function in heifers. Theriogenology 53: 963-979

TAN GJS, TWEEDALE R, BIGGS JSG 1982: Effects of oxytocin on the bovine corpus luteum of early pregnancy. J Reprod Fertil 66: 75-78

THATCHER WW, STAPLES CR, DANET-DESNOYERS G, OLDICK B, SCHMITT EP 1994: Embryo health and mortality in sheep and cattle. J Anim Sci 72 (Suppl 3): 16-30

WATHES DC, AYAD VJ, GILBERT CL, MCGOFF SA, WATHES CM 1991: Influence of oxytocin infusion during the oestrus and the early luteal phase on progesterone secretion and the establishment of pregnancy in ewes. J Reprod Fertil 92: 383-391

WILMUT I, SALES DC, ASHWORTH CD 1985: The influence of variation in embryo stage and maternal hormone profiles on embryo survival in farm animals. Theriogenology 23: 107-119

YILDIZ A 1999: Diagnosis of pregnancy by determining early pregnancy factor (EPF) in cows. PhD. Thesis, FU Sag Bil Enst Elaz_g, Turkey, pp. 11-14.

YILDIZ A, DEVECI H 2000: Diagnosis of pregnancy by determining early pregnancy factor (EPF) in cows. FU Sag Bil Enst Derg 14: 85-92 